\title{
Chemical Synthesis and NMR Characterization of Non Steroidal Mimics of an Estradiol Derivative Used as Inhibitor of $17 \beta$-Hydroxysteroid Dehydrogenase Type 1
}

\author{
Guy Bertrand Djigoué ${ }^{1}$, René Maltais ${ }^{1}$, Charles Ouellet ${ }^{1}$, Alexandre Trottier $^{1} \&$ Donald Poirier $^{1}$ \\ ${ }^{1}$ Laboratory of Medicinal Chemistry, CHUQ (CHUL)-Research Center and Laval University, Québec, Canada \\ Correspondence: Donald Poirier, Laboratory of Medicinal Chemistry, CHUQ (CHUL)-Research Center, Québec, \\ QC., G1V 4G2, Canada. Tel: 1-418-654-2296. E-mail: Donald.poirier@crchul.ulaval.ca
}

Received: October 8, 2012 Accepted: October 22, 2012 Online Published: November 27, 2012

doi:10.5539/ijc.v4n6p75 URL: http://dx.doi.org/ijc.v4n6p75

\begin{abstract}
Inhibiting estradiol (E2) biosynthesis through 17ß-hydroxysteroid dehydrogenase type 1 (17ß-HSD1) inhibitors is a promising strategy for breast cancer therapy. We have designed a non-steroidal template to mimic CC-156, a potent steroidal inhibitor of 173-HSD1. Starting from tetrahydro-isoquinolinol hydrobromide, two representative compounds were synthesized in six chemical steps: protection of the amino group, protection of the phenol, hydrolysis of the N-protecting group Fmoc, nucleophilic substitution to introduce an ethyloxirane, phenolysis with meta or para hydroxybenzamide and the hydrolysis of the MOM protecting group. Although the compounds showed a good fit when docked in the catalytic site of the enzyme, conserving the key interactions with amino acids His221 and Ser142, observed from the crystalline structure of inhibitor CC-156 with $17 \beta$-HSD1, they weakly inhibited 17ß-HSD1. However, they did not show estrogenic activity when tested in vitro, suggesting the potential of this non-steroidal template for drug design. Furthermore, the synthetic approach reported here opens a door to the preparation of additional non-steroidal mimics of E2 derivatives, which could be tested on $17 \beta$-HSD1 and others biological targets.
\end{abstract}

Keywords: phenol derivative, tetrahydro-isoquinolinol, chemical synthesis, inhibitor, 17ß-hydroxysteroid dehydrogenase

\section{Introduction}

Breast cancer is the leading cause of death worldwide among all the types of cancers affecting women (Jemal et al., 2011). Estrogenic hormones are important stimulators in most of these breast cancers (Dizerega et al., 1980; Travis \& Key, 2003) and estradiol (E2), the most potent natural estrogen, stimulates cancer cell growth through endocrine, paracrine, and intracrine pathways (Labrie, 1991). The last step in E2 biosynthesis requires the enzyme $17 \beta$-hydroxysteroid dehydrogenase type 1 (17 $\beta$-HSD1). This enzyme also catalyses the reduction of

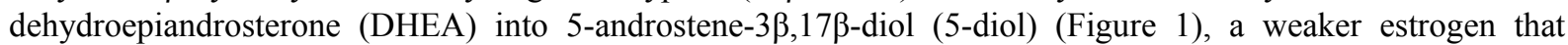
becomes more important after menopause (Simard et al., 1988).

Blocking 17ß-HSD1 thus appears to be an attractive strategy in breast cancer therapy (Poirier, 2008). To the best of our knowledge, there is still no $17 \beta-H S D 1$ inhibitor under clinical trials. This is partly explained by the fact that many potent inhibitors of this enzyme have an estrane nucleus that can activate the estrogen receptors (ERs). Of course it is not desirable to use these estrogenic inhibitors in the treatment of hormone-dependent breast cancer, and synthesizing 17ß-HSD1 inhibitors without estrogenic activity thus represents a great challenge (Poirier, 2010; Poirier, 2011; Day et al., 2008b). Compound CC-156 (Figure 2A) is a very potent inhibitor of 17ß-HSD1 that was synthesized and reported from previous work in our laboratory (Laplante et al., 2008). The crystal structure of the ternary complex of CC-156 with $17 \beta$-HSD1 and cofactor NADP has already been described (Figure 2B) (Mazundar et al., 2009) and shown key interactions with amino acids in the enzyme catalytic site. However, this compound was found to stimulate the proliferation of MCF-7 and T-47D estrogen-sensitive (ER ${ }^{+}$) breast cancer cell lines, thus greatly reducing its therapeutic potential. Three strategies were tried to reduce the proliferative (estrogenic) effect of this steroidal inhibitor: Replacing the hydroxy group at position 3 (C3) by a hydrogen atom; adding a methoxy at $\mathrm{C} 2$; or adding an alkylamide chain at $\mathrm{C} 7$, but all these methods did not give satisfactory results (Laplante et al., 2008). 


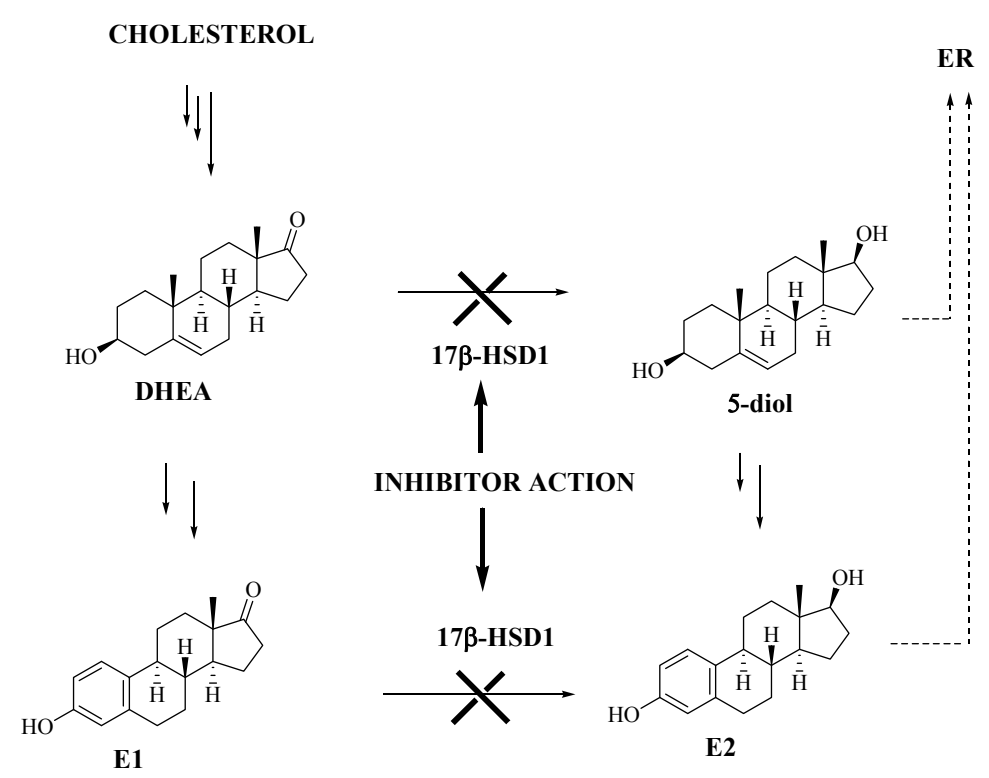

Figure 1. Last steps in the biosynthesis of active estrogens estradiol (E2) and 5-androstene-3 $\beta, 17 \beta$-diol (5-diol), which stimulate the cell proliferation by their action on the estrogen receptor (ER)

B

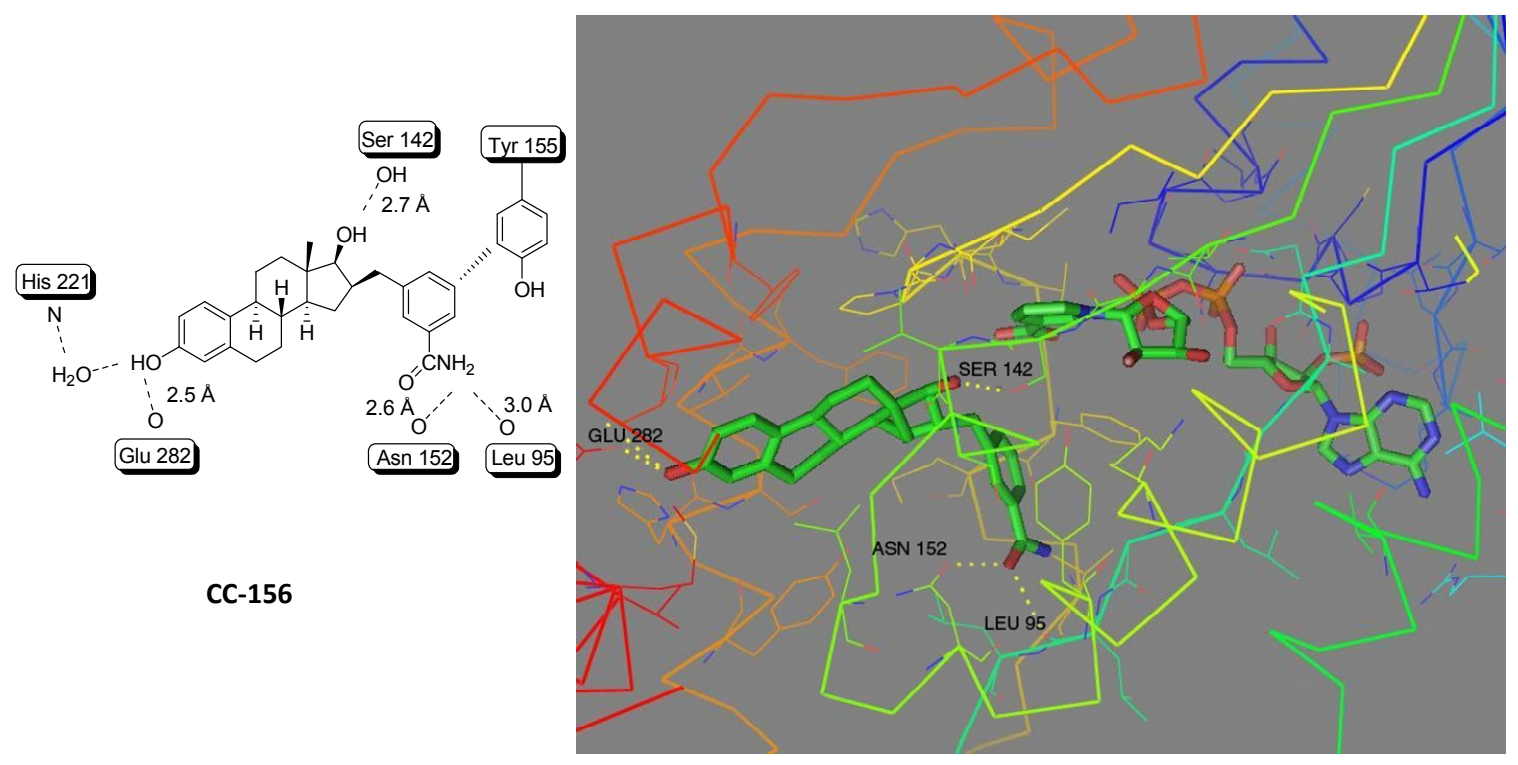

Figure 2. Analysis of the crystalline structure of the ternary complex 17 $\beta$-HSD1/CC-156/NADP. 2D (A) and 3D (B) representations showing interactions (H-bond and $\pi-\pi$ interactions) between the enzyme (17ß-HSD1) and the inhibitor (CC-156) (Mazumdar et al., 2009)

Using AutoDock software (http://autodock.scripps.edu/), we found that compound 10 (Figure 3A) fits very well in the enzyme catalytic site of 17ß-HSD1 (Figure 3B). We also observed that compound 10 keeps interactions with His221 and Ser142; its phenyl ether moiety interacts with Tyr155 differently (with H-bond) regarding to CC-156 in which it binds via $\pi \pi$ interaction (Mazumdar et al., 2009); and new hydrogen bonds were observed with Val188, Thr190 and Val143. Such non-steroidal compound is interesting because it is expected to be an E2 mimic without residual estrogenic activity. Herein, we report the successful synthesis of 8 and 10, two mimics of CC-156, starting from tetrahydro-6-isoquinolinol hydrobromide (1) (Figure 4). We also report their characterization by IR, ${ }^{1} \mathrm{H}$ NMR, ${ }^{13} \mathrm{C}$ NMR and MS analyses, their assessment as inhibitor of $17 \beta-\mathrm{HSD} 1$, and 
their assessment as estrogenic compounds.

A

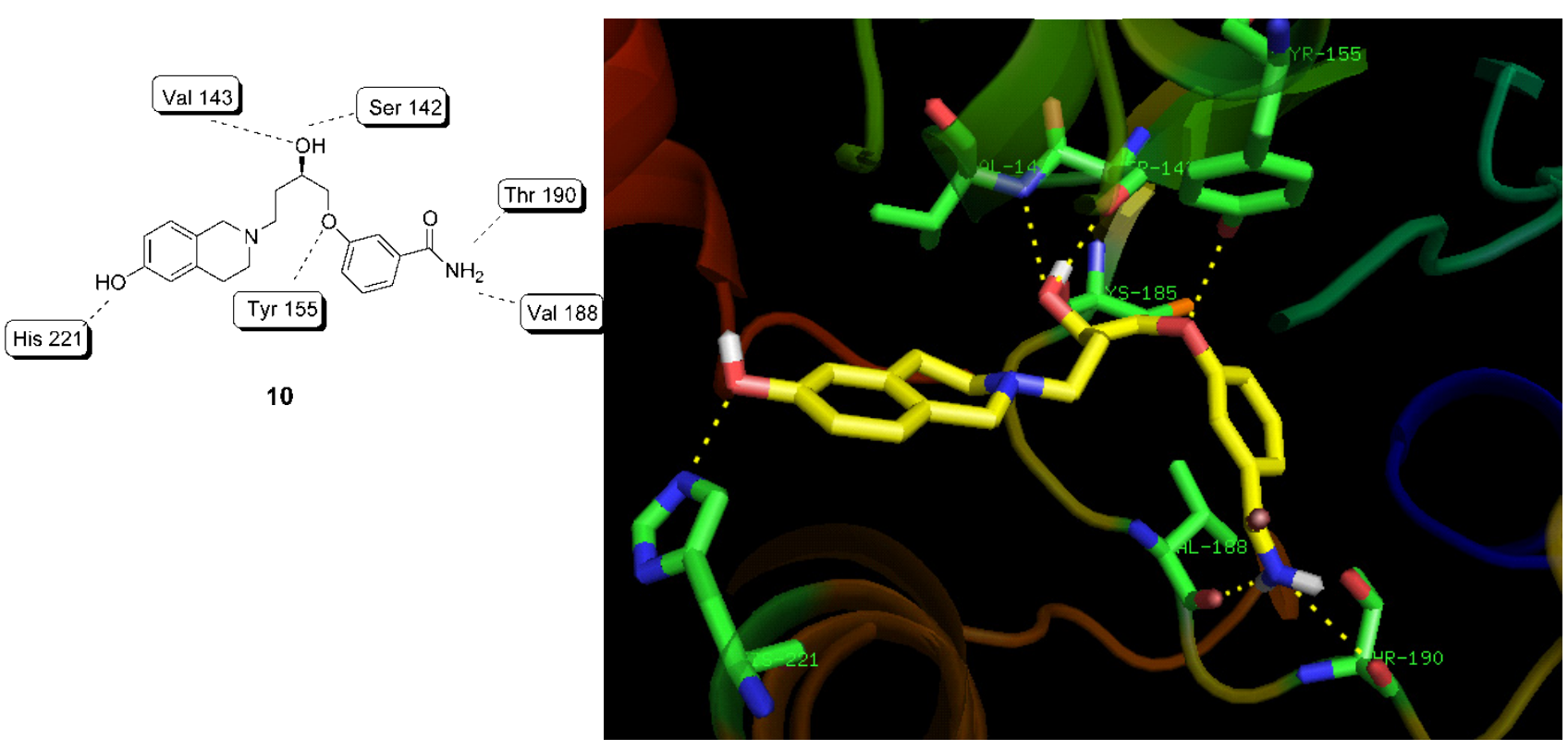

Figure 3. 2D (A) and 3D (B) representations of different interactions observed between the non-steroidal mimic of CC-156 (compound 10) and 17ß-HSD1 after a docking experiment (AutoDock v.3). Calculated energy $=-11.4$ $\mathrm{kcal} / \mathrm{mol}$

\section{Experimental}

\subsection{General}

1,2,3,4-Tetrahydroisoquinolin-6-ol hydrobromide was purchased from Ark Pharm (Libertyville, IL, USA). 4-Hydroxybenzamide and chemical reagents of highest purity were obtained from Sigma-Aldrich Canada Ltd. (Oakville, ON, Canada), N-(9-fluorenylmethoxycarbonyloxy) succinimide (Fmoc-OSu) was purchased from Novabiochem (Darmstadt, Germany). Solvents were obtained from Fisher Scientific (Montréal, QC, Canada). Reactions were run under an inert (argon) atmosphere in oven-dried glassware. Analytical thin-layer chromatography (TLC) was performed on $0.20 \mathrm{~mm}$ silica gel 60 F254 plates (E. Merck, Darmstadt, Germany), and compounds were visualized by using ammonium molybdate/sulfuric acid/water (with heating). Flash column chromatography was performed with Silicycle R10030B 230-400 mesh silica gel (Québec, QC, Canada). Infrared spectra (IR) were obtained from a thin film of compound usually solubilised in $\mathrm{CH}_{2} \mathrm{Cl}_{2}$ (DCM) and deposited upon a $\mathrm{NaCl}$ pellet. They were recorded with a Horizon MB 3000 ABB FTIR spectrometer (ABB, Québec, QC, Canada) and bands are reported in $\mathrm{cm}^{-1}$. Nuclear magnetic resonance (NMR) spectra were recorded with a Bruker Avance 400 digital spectrometer (Billerica, MA, USA) and data reported in ppm. The $\mathrm{CDCl}_{3}{ }^{1} \mathrm{H}$ and ${ }^{13} \mathrm{C}$ NMR signals (7.26 and $77.0 \mathrm{ppm}$, respectively) and $\mathrm{CD}_{3} \mathrm{OD}{ }^{1} \mathrm{H}$ and ${ }^{13} \mathrm{C}$ NMR signals (3.31 and 49.0 ppm, respectively) were used as internal references. Low-resolution mass spectra (LRMS) were recorded on a PE Sciex API-150ex apparatus (Foster City, CA, USA) equipped with a turbo ion-spray source.

\subsection{Synthesis of Fmoc-protected Compound 2}

1,2,3,4-Tetrahydroisoquinolin-6-ol hydrobromide (1) $(9.0 \mathrm{~g}, 39.1 \mathrm{mmol})$ was dissolved in a mixture of THF/water $(3 / 1 \mathrm{v} / \mathrm{v})$ and an aqueous $1 \mathrm{~N}$ sodium bicarbonate solution $(117 \mathrm{~mL})$ was added. After the reaction mixture was stirred $5 \mathrm{~min}, \mathrm{Fmoc}-\mathrm{OSu}(13.9 \mathrm{~g}, 41.1 \mathrm{mmol})$ was added and the mixture stirred for $2 \mathrm{~h}$ at room temperature. Water $(450 \mathrm{~mL})$ was added and the crude product was extracted with EtOAc. The organic phase was dried with anhydrous $\mathrm{Na}_{2} \mathrm{SO}_{4}$, filtered and evaporated under reduced pressure. Compound $2(14.0 \mathrm{~g}, 96 \%$ yield) was obtained as a white powder after purification by chromatography (hexanes/EtOAc; 1/1).

9H-Fluoren-9-ylmethyl 6-hydroxy-3,4-dihydroisoquinoline-2(1H)-carboxylate (2): $\mathrm{Rf}=0.25$ (hexanes/EtOAc, 8:2). IR (film) v $3317(\mathrm{OH}), 2947,2901,1674(\mathrm{NCOO}), 1612,1443,1221 .{ }^{1} \mathrm{H}$ NMR $\left(\mathrm{CDCl}_{3}\right) \delta 2.77(\mathrm{~m}$, 
$\mathrm{Ar}-\mathrm{CH}_{2}-\mathrm{CH}_{2}$ ), $3.67\left(\mathrm{~m}, \mathrm{CH}_{2}-\mathrm{CH}_{2}-\mathrm{N}\right), 4.28\left(\mathrm{t}, \mathrm{J}=6.8 \mathrm{~Hz}, \mathrm{CH}\right.$ of Fmoc), 4.47 (d, J = 6.8 Hz, $\mathrm{CH}_{2}$ of Fmoc), 4.55 (m, $\left.\mathrm{Ar}-\mathrm{CH}_{2}-\mathrm{N}\right), 6.63(\mathrm{~d}, \mathrm{~J}=2.5 \mathrm{~Hz}, \mathrm{CH}$ of $\mathrm{Ar}), 6.64$ and $6.83(2 \mathrm{~m}, 2 \mathrm{x} \mathrm{CH}$ of $\mathrm{Ar}), 7.31,7.40,7.60$ and 7.77 (4m, $8 \mathrm{xCH}$ of Fmoc) ${ }^{13} \mathrm{C}$ NMR $\left(\mathrm{CDCl}_{3}\right) \delta 28.7,41.4,45.3,47.3,67.5,114.9,115.1,120.0(2 \mathrm{x}), 125.0(2 \mathrm{x}), 127.0$ (2x), 127.4, $127.7(2 \mathrm{x}), 133.1,135.9,141.3(2 \mathrm{x}), 144.0(2 \mathrm{x}), 154.2,155.5$. LRMS calculated for $\mathrm{C}_{24} \mathrm{H}_{22} \mathrm{NO}_{3}$ $(\mathrm{M}+\mathrm{H}) 372.15$, found 372.30 .

\subsection{Synthesis of MOM and Fmoc-protected Compound 3}

To a solution of compound $2(14.0 \mathrm{~g}, 37.6 \mathrm{mmol})$ in anhydrous DCM $(1000 \mathrm{~mL})$ under an argon atmosphere was added $\mathrm{N}, \mathrm{N}$-diisopropylethylamine $\left(15.7 \mathrm{~mL}\right.$ ) and the mixture was stirred for $10 \mathrm{~min}$ at $0^{\circ} \mathrm{C}$ (in an ice/water bath) Chloromethyl methyl ether $(5.43 \mathrm{~g}, 67.4 \mathrm{mmol})$ was then added slowly and the reaction mixture was brought to room temperature after $20 \mathrm{~min}$ and stirred for $24 \mathrm{~h}$. Water was added to quench the reaction and the mixture extracted with DCM. The organic phase was dried with anhydrous $\mathrm{Na}_{2} \mathrm{SO}_{4}$, filtered and evaporated under reduced pressure. The crude mixture was purified by flash chromatography (hexanes/EtOAc; $3 / 1$ ) to provide compound 3 (11.0 g, 70\% yield).

9H-Fluoren-9-ylmethyl 6-(methoxymethoxy)-3,4-dihydroisoquinoline-2(1H)-carboxylate $\quad(3)$ : $\quad \mathrm{Rf}=0.38$ (hexanes/EtOAc, 8:2). IR (film) v 2947, 2901, 1697 (NCOO), 1612, 1504, 1427, 1227, 1149, 1095, 1011. ${ }^{1} \mathrm{H}$ $\operatorname{NMR}\left(\mathrm{CDCl}_{3}\right) \delta 2.81\left(\mathrm{~m}, \mathrm{Ar}-\mathrm{CH}_{2}-\mathrm{CH}_{2}\right), 3.49\left(\mathrm{~s}, \mathrm{CH}_{3} \mathrm{O}\right), 3.68\left(\mathrm{~m}, \mathrm{CH}_{2}-\mathrm{CH}_{2}-\mathrm{N}\right), 4.28(\mathrm{t}, \mathrm{J}=6.8 \mathrm{~Hz}, \mathrm{CH}$ of Fmoc),

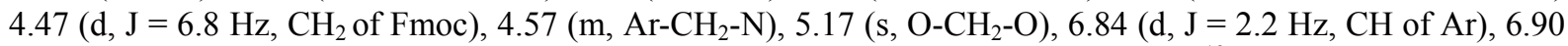
(m, $\mathrm{CH}$ of $\mathrm{Ar}$ ), 7.03 (m, CH of Ar), 7.31, 7.39, 7.59 and 7.75 (4m, 8 x CH of Fmoc). ${ }^{13} \mathrm{C} \mathrm{NMR}\left(\mathrm{CDCl}_{3}\right) \delta 28.7$, 41.2, 45.1, 47.2, 55.8, 67.2, 94.3, 114.6, 115.8, $119.8(2 \mathrm{x}), 124.8(2 \mathrm{x}), 126.3,126.9(2 \mathrm{x}), 127.1,127.5(2 \mathrm{x}), 135.5$, 141.2 (2x), $143.9(2 \mathrm{x}), 155.2$, 155.6. LRMS calculated for $\mathrm{C}_{26} \mathrm{H}_{26} \mathrm{NO}_{4}(\mathrm{M}+\mathrm{H}) 416.18$, found 416.30 .

\subsection{Fmoc Hydrolysis: Synthesis of Compound 4}

Compound $3(11.0 \mathrm{~g}, 26.4 \mathrm{mmol})$ was dissolved in anhydrous DCM $(220 \mathrm{~mL})$ and piperidine $(55 \mathrm{~mL})$. The reaction mixture was stirred for $1 \mathrm{~h}$ at room temperature and then quenched with water. The organic phase was washed with water and dried with anhydrous $\mathrm{Na}_{2} \mathrm{SO}_{4}$, filtered and evaporated under reduced pressure. The yellowish powder was purified by flash chromatography (DCM/MeOH; 97:3) to provide compound 4 ( $2.9 \mathrm{~g}, 55 \%$ yield).

6-(Methoxymethoxy)-1,2,3,4-tetrahydroisoquinoline (4): $\mathrm{Rf}=0.24$ (hexanes/EtOAc, 3:1). IR (film) v 3317 (NH), 2924, 1612, 1504, 1234, 1149, 1072, 1003. ${ }^{1} \mathrm{H}$ NMR $\left(\mathrm{CD}_{3} \mathrm{OD}\right) \delta 2.84\left(\mathrm{t}, \mathrm{J}=6.0 \mathrm{~Hz}, \mathrm{Ar}-\mathrm{CH}_{2}-\mathrm{CH}_{2}\right), 3.11(\mathrm{t}, \mathrm{J}=$ $\left.6.1 \mathrm{~Hz}, \mathrm{CH}_{2}-\mathrm{CH}_{2}-\mathrm{N}\right), 3.45\left(\mathrm{~s}, \mathrm{CH}_{3} \mathrm{O}\right), 3.95\left(\mathrm{~s}, \mathrm{Ar}^{-\mathrm{CH}_{2}-\mathrm{N}}\right), 5.15\left(\mathrm{~s}, \mathrm{O}_{-} \mathrm{CH}_{2}-\mathrm{O}\right), 6.80$ (s, $\mathrm{CH}$ of $\left.\mathrm{Ar}\right), 6.83$ (d, J = 8.3 $\mathrm{Hz}, 1 \mathrm{H}, \mathrm{CH}$ of pseudo A ring), $6.97(\mathrm{~d}, \mathrm{~J}=8.3 \mathrm{~Hz}, \mathrm{CH}$ of $\mathrm{Ar}){ }^{13} \mathrm{C}_{\mathrm{NMR}}\left(\mathrm{CDCl}_{3}\right) \delta$ 29.3, 43.6, 47.6, 55.9, 94.5, 114.3, 116.5, 127.5, 129.3, 135.5, 155.4. LRMS calculated for $\mathrm{C}_{11} \mathrm{H}_{16} \mathrm{NO}_{2}(\mathrm{M}+\mathrm{H})$ 194.11, found 194.15.

\subsection{Synthesis of Epoxide 5}

To a solution of amine $4(245 \mathrm{mg}, 1.3 \mathrm{mmol})$ and potassium carbonate $(261 \mathrm{mg}, 1.9 \mathrm{mmol})$ in acetone $(12 \mathrm{~mL})$ was added 4-bromo-1,2-epoxybutane $(476 \mathrm{mg}, 3.2 \mathrm{mmol})$ and the mixture was stirred for $16 \mathrm{~h}$ at $55^{\circ} \mathrm{C}$. The solution was filtered over a büchner and rinsed with DCM, then the collected filtrate was evaporated under reduced pressure and purified by flash chromatography (hexanes/EtOAc/triethylamine; 90/9/1) to yield epoxide 5 (216 $\mathrm{mg}, 65 \%$ yield).

6-(Methoxymethoxy)-2-[2-(oxiran-2-yl)ethyl]-1,2,3,4-tetrahydroisoquinoline (5): $\mathrm{Rf}=0.28$ (DCM/MeOH, 9:1). IR (film) v 2924, 1612, 1504, 1242, 1149, 1076, 1011. ${ }^{1} \mathrm{H}$ NMR $\left(\mathrm{CDCl}_{3}\right) \delta 1.78$ and $1.87\left(2 \mathrm{~m}, \underline{\mathrm{CH}}_{2}-\mathrm{CH}-\mathrm{O}\right), 2.54$

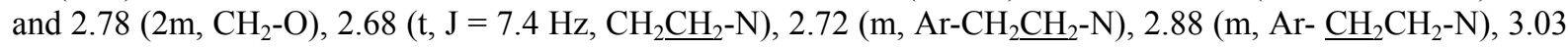
(m, $\mathrm{CH}-\mathrm{O}), 3.47\left(\mathrm{~s}, \mathrm{CH}_{3} \mathrm{O}\right), 3.59\left(\mathrm{~s}, \mathrm{Ar}_{-} \mathrm{CH}_{2}-\mathrm{N}\right), 5.14\left(\mathrm{~s}, \mathrm{O}_{-} \mathrm{CH}_{2}-\mathrm{O}\right), 6.79(\mathrm{~d}, \mathrm{~J}=3.0 \mathrm{~Hz}, \mathrm{CH}$ of Ar$), 6.81(\mathrm{~d}, \mathrm{~J}=$ $8.3 \mathrm{~Hz}, \mathrm{CH}$ of Ar), $6.94(\mathrm{~d}, \mathrm{~J}=8.2 \mathrm{~Hz}, \mathrm{CH}$ of $\mathrm{Ar}) .{ }^{13} \mathrm{C} \mathrm{NMR}\left(\mathrm{CDCl}_{3}\right) \delta 29.3,30.5,47.1,50.8,50.9,54.7,55.6$, $55.9,94.5,114.2,115.8,127.5,128.2,135.5,155.5$. LRMS calculated for $\mathrm{C}_{15} \mathrm{H}_{22} \mathrm{NO}_{3}(\mathrm{M}+\mathrm{H}) 264.15$, found 264.15 .

\subsection{General Method for the Synthesis of Compounds 6 and 7}

To a solution of 4-hydroxybenzamide or 3-hydroxybenzamide (104 $\mathrm{mg}, 0.76 \mathrm{mmol})$ in DMF $(10 \mathrm{~mL})$ was added potassium carbonate $(158 \mathrm{mg}, 1.14 \mathrm{mmol})$ and the mixture was stirred for $30 \mathrm{~min}$ under argon at $105^{\circ} \mathrm{C}$. The epoxide $5(100 \mathrm{mg}, 0.38 \mathrm{mmol})$ was dissolved in DMF $(3 \mathrm{~mL})$ and added to the reaction mixture. After $22 \mathrm{~h}$ at $105^{\circ} \mathrm{C}$, water $(14 \mathrm{~mL})$ and a saturated aqueous sodium bicarbonate solution $(10 \mathrm{~mL})$ were added and the mixture extracted with EtOAc. The organic phase was dried with $\mathrm{Na}_{2} \mathrm{SO}_{4}$ filtered, evaporated under reduced pressure and purified by flash chromatography (DCM/MeOH; 98:2 to 95:5) to yield the compound 6 (69 $\mathrm{mg}, 45 \%$ yield) or 7 (33 mg, 21\% yield). 
4-\{2-Hydroxy-4-[6-(methoxymethoxy)-3,4-dihydroisoquinolin-2(1H)-yl]butoxy\}benzamide (6): $\mathrm{Rf}=0.40$ (DCM/MeOH, 9:1). IR (film) v 3391 and $3190\left(\mathrm{OH}\right.$ and $\mathrm{NH}_{2}$ ), 2928, 2827, 2762, 1647 (CON, amide), 1612, 1574, 1508, 1423, 1400, 1311, 1261, 1149, 1076, 1022. ${ }^{1} \mathrm{H}$ NMR $\left(\mathrm{CDCl}_{3}\right) \delta 1.90\left(\mathrm{~m}, \underline{\mathrm{CH}}_{2}-\mathrm{CH}-\mathrm{O}\right), 2.68$ and 2.94 (2m, Ar- $\left.\mathrm{CH}_{2} \mathrm{CH}_{2}-\mathrm{N}\right), 2.87\left(\mathrm{~m}, \mathrm{CH}_{2} \mathrm{CH}_{2}-\mathrm{N}\right.$ and $\left.\mathrm{Ar}-\mathrm{CH}_{2} \mathrm{CH}_{2}-\mathrm{N}\right), 3.47\left(\mathrm{~s}, \mathrm{CH}_{3} \mathrm{O}\right), 3.62$ and $3.74(2 \mathrm{~d}$ of AB system, $\left.\mathrm{J}=14.5 \mathrm{~Hz}, \mathrm{Ar}-\mathrm{CH}_{2}-\mathrm{N}\right), 3.94\left(\mathrm{dd}, \mathrm{J}_{1}=5.9 \mathrm{~Hz}\right.$ and $\mathrm{J}_{2}=9.3 \mathrm{~Hz}, 1 \mathrm{H}$ of $\left.\mathrm{OCH}_{2}\right), 4.04\left(\mathrm{dd}, \mathrm{J}_{1}=5.4 \mathrm{~Hz}\right.$ and $\mathrm{J}_{2}=9.3$ $\mathrm{Hz}, 1 \mathrm{H}$ of $\left.\mathrm{OCH}_{2}\right), 4.23(\mathrm{~m}, \mathrm{CHO}), 5.14\left(\mathrm{~s}, \mathrm{O}_{-} \mathrm{CH}_{2}-\mathrm{O}\right), 6.79\left(\mathrm{~d}, \mathrm{~J}=2.3 \mathrm{~Hz}, \mathrm{CH}\right.$ of Ar), $6.83\left(\mathrm{dd}, \mathrm{J}_{1}=2.5 \mathrm{~Hz}\right.$ and $\mathrm{J}_{2}=8.3 \mathrm{~Hz}, \mathrm{CH}$ of Ar), $6.95(\mathrm{~d}, \mathrm{~J}=8.7 \mathrm{~Hz}, \mathrm{CH}$ of Ar), $6.96(\mathrm{~d}, \mathrm{~J}=8.9 \mathrm{~Hz}, 2 \times \mathrm{CH}$ of benzamide $), 7.76(\mathrm{~d}, \mathrm{~J}=$ $8.8 \mathrm{~Hz}, 2 \mathrm{x} \mathrm{CH}$ of benzamide). ${ }^{13} \mathrm{C} \mathrm{NMR}\left(\mathrm{CDCl}_{3}\right) \delta 28.5,29.1,50.5,55.7,55.9,56.8,71.5,71.8,94.5,114.3(2 \mathrm{x})$, 114.4, 115.8, 125.7, 127.4, 127.5, 129.3 (2x), 135.1, 155.7, 161.9, 168.9. LRMS calculated for $\mathrm{C}_{22} \mathrm{H}_{28} \mathrm{~N}_{2} \mathrm{O}_{5}$ $(\mathrm{M}+\mathrm{H})$ 401.20, found 401.20.

3-\{2-Hydroxy-4-[6-(methoxymethoxy)-3,4-dihydroisoquinolin-2(1H)-yl]butoxy $\}$ benzamide (7): $\mathrm{Rf}=0.30$ (DCM/MeOH, 9:1). IR (film) v 3348 and $3198\left(\mathrm{OH}\right.$ and $\left.\mathrm{NH}_{2}\right), 2932,2827,1666$ (CON, amide), 1612, 1582, 1504, 1447, 1381, 1246, 1153, 1076, 1011. ${ }^{1} \mathrm{H}$ NMR $\left(\mathrm{CDCl}_{3}\right) \delta 1.88\left(\mathrm{~m}, \mathrm{CH}_{2}-\mathrm{CH}-\mathrm{O}\right), 2.67$ and $3.05(2 \mathrm{~m}$, Ar- $\left.\mathrm{CH}_{2} \mathrm{CH}_{2}-\mathrm{N}\right), 2.87\left(\mathrm{~m}, \mathrm{CH}_{2} \mathrm{CH}_{2}-\mathrm{N}\right.$ and $\left.\mathrm{Ar}-\mathrm{CH}_{2} \mathrm{CH}_{2}-\mathrm{N}\right), 3.47\left(\mathrm{~s}, \mathrm{CH}_{3} \mathrm{O}\right), 3.63$ and $3.74(2 \mathrm{~d}$ of AB system, $\mathrm{J}=$ $\left.14.5 \mathrm{~Hz}, \mathrm{Ar}-\mathrm{CH}_{2}-\mathrm{N}\right), 3.93\left(\mathrm{dd}, \mathrm{J}_{1}=5.6 \mathrm{~Hz}\right.$ and $\mathrm{J}_{2}=9.4 \mathrm{~Hz}, 1 \mathrm{H}$ of $\left.\mathrm{OCH}_{2}\right), 4.05\left(\mathrm{dd}, \mathrm{J}_{1}=5.5 \mathrm{~Hz}\right.$ and $\mathrm{J}_{2}=9.4 \mathrm{~Hz}$, $1 \mathrm{H}$ of $\left.\mathrm{OCH}_{2}\right), 4.23(\mathrm{~m}, \mathrm{CH}-\mathrm{O}), 5.14\left(\mathrm{~s}, \mathrm{O}-\mathrm{CH}_{2}-\mathrm{O}\right), 6.78\left(\mathrm{~d}, \mathrm{~J}=2.3 \mathrm{~Hz}, \mathrm{CH}\right.$ of Ar), $6.82\left(\mathrm{dd}, \mathrm{J}_{1}=2.5 \mathrm{~Hz}\right.$ and $\mathrm{J}_{2}=$ $8.4 \mathrm{~Hz}, \mathrm{CH}$ of $\mathrm{Ar}$ ), 6.95 (d, J = 8.4 Hz, CH of Ar), 7.10 (m, CH of benzamide), 7.33 (m, 2 x CH of benzamide) 7.41 (s, $\mathrm{CH}$ of benzamide). ${ }^{13} \mathrm{C}$ NMR $\left(\mathrm{CDCl}_{3}\right) \delta 28.5,29.0,50.5,55.6,55.9,56.6,71.4,71.9,94.5,113.4,114.5$, 115.7, 118.6, 119.5, 127.2, 127.5, 129.6, 134.8, 135.1, 155.7, 159.0, 169.2. LRMS calculated for $\mathrm{C}_{22} \mathrm{H}_{28} \mathrm{~N}_{2} \mathrm{O}_{5}$ $(\mathrm{M}+\mathrm{H})$ 401.20, found 401.20.

\subsection{Hydrolysis of the MOM Group: Synthesis of 8 and 9}

Compound $6(68 \mathrm{mg}, 0.17 \mathrm{mmol})$ was dissolved in methanol $(2 \mathrm{~mL})$, a solution of hydrochloric acid $(20 \%$ in methanol) $(6.2 \mathrm{~mL})$ was added and the resulting mixture was heated $4.5 \mathrm{~h}$ at $65^{\circ} \mathrm{C}$. Water was then added, the methanol evaporated under reduced pressure, the solution neutralised with a saturated aqueous solution of sodium bicarbonate, and the aqueous phase extracted with DCM. The organic phase was evaporated and the yellowish powder was purified by flash chromatography (DCM/MeOH; 98:2) to yield the expected compound 8 (18 $\mathrm{mg}, 29 \%$ yield) and the ester 9 (14.5 mg, 23\% yield).

4-[2-Hydroxy-4-(6-hydroxy-3,4-dihydroisoquinolin-2(1H)-yl)butoxy]benzamide (8): $\mathrm{Rf}=0.10$ (DCM/MeOH, 9:1). IR (film) v 3344 and $3178\left(\mathrm{OH}\right.$ and $\left.\mathrm{NH}_{2}\right), 2924,2851,1655$ (CON, amide), 1605, 1570, 1512, 1458, 1381, 1254, 1180, 1126. ${ }^{1} \mathrm{H}$ NMR $\left(\mathrm{CD}_{3} \mathrm{OD}\right) \delta 2.00\left(\mathrm{~m}, \mathrm{CH}_{2}-\mathrm{CH}-\mathrm{O}\right), 2.96$ and $3.08\left(2 \mathrm{~m}, \mathrm{Ar}-\mathrm{CH}_{2} \mathrm{CH}_{2}-\mathrm{N}-\mathrm{CH}_{2}\right), 3.90(\mathrm{~s}$, $\left.\mathrm{Ar}-\underline{\mathrm{CH}}_{2}-\mathrm{N}\right), 4.05\left(\mathrm{~m}, \mathrm{Ph}-\underline{\mathrm{CH}}_{2} \underline{\mathrm{CHO}}\right), 6.60\left(\mathrm{~d}, \mathrm{~J}=2.3 \mathrm{~Hz}, \mathrm{CH}\right.$ of Ar), $6.64\left(\mathrm{dd}, \mathrm{J}_{1}=2.5 \mathrm{~Hz}\right.$ and $\mathrm{J}_{2}=8.3 \mathrm{~Hz}, \mathrm{CH}$ of $\mathrm{Ar}), 6.95(\mathrm{~d}, \mathrm{~J}=8.3 \mathrm{~Hz}, \mathrm{CH}$ of $\mathrm{Ar}), 7.04(\mathrm{~d}, \mathrm{~J}=8.9 \mathrm{~Hz}, 2 \times \mathrm{CH}$ of benzamide), $7.87(\mathrm{~d}, \mathrm{~J}=8.9 \mathrm{~Hz}, 2 \mathrm{x} \mathrm{CH}$ of benzamide). ${ }^{13} \mathrm{C}$ NMR $\left(\mathrm{CD}_{3} \mathrm{OD}\right) \delta 28.6,30.3,51.7,55.8,55.9,69.7,73.2,115.0,115.3(2 \mathrm{x}), 115.7,123.8,127.3$, 128.8, 130.7 (2x), 135.1, 157.6, 163.3, 172.0. LRMS calculated for $\mathrm{C}_{20} \mathrm{H}_{25} \mathrm{~N}_{2} \mathrm{O}_{4}(\mathrm{M}+\mathrm{H}) 357.17$, found 357.15.

Methyl 3-[2-hydroxy-4-(6-hydroxy-3,4-dihydroisoquinolin-2(1H)-yl)butoxy]benzoate $\quad(9)$ : $\quad \mathrm{Rf}=0.40$ (DCM/MeOH, 9:1). IR (film) v 3209 and 3055 (OH phenol and alcohol), 2947, 2831, 1713 (C=O, ester), 1605, 1512, 1435, 1281, 1257, 1173, 1111, 1034. ${ }^{1} \mathrm{H}$ NMR $\left(\mathrm{CDCl}_{3}\right) \delta 1.87$ (m, $\left.\underline{\mathrm{CH}}_{2}-\mathrm{CH}-\mathrm{O}\right), 2.65$ and 2.85 (2m, $\left.\mathrm{Ar}-\mathrm{CH}_{2} \mathrm{CH}_{2}-\mathrm{N}-\mathrm{CH}_{2}\right), 3.57$ and $3.70\left(2 \mathrm{~d}\right.$ of AB system, J = $\left.14.1 \mathrm{~Hz}, \mathrm{Ar}-\mathrm{CH}_{2}-\mathrm{N}\right), 3.88\left(\mathrm{~s}, \mathrm{CH}_{3} \mathrm{O}\right), 3.96\left(\mathrm{dd}, \mathrm{J}_{1}=5.9\right.$ $\mathrm{Hz}$ and $\mathrm{J}_{2}=9.4 \mathrm{~Hz}, 1 \mathrm{H}$ of $\left.\mathrm{OCH}_{2}\right), 4.06\left(\mathrm{dd}, \mathrm{J}_{1}=5.3 \mathrm{~Hz}\right.$ and $\mathrm{J}_{2}=9.4 \mathrm{~Hz}, 1 \mathrm{H}$ of Ph-OCH $), 4.28(\mathrm{~m}, \mathrm{CH}-\mathrm{O}), 6.43$ $(\mathrm{d}, \mathrm{J}=2.4 \mathrm{~Hz}, \mathrm{CH}$ of $\mathrm{Ar}), 6.56\left(\mathrm{dd}, \mathrm{J}_{1}=2.5 \mathrm{~Hz}\right.$ and $\mathrm{J}_{2}=10.8 \mathrm{~Hz}, \mathrm{CH}$ of Ar), $6.79(\mathrm{~d}, \mathrm{~J}=8.3 \mathrm{~Hz}, \mathrm{CH}$ of Ar), 6.94 $\left(\mathrm{d}, \mathrm{J}=8.9 \mathrm{~Hz}, 2 \mathrm{x} \mathrm{CH}\right.$ of methylbenzoate), $7.98\left(\mathrm{~d}, \mathrm{~J}=8.9 \mathrm{~Hz}, 2 \mathrm{x} \mathrm{CH}\right.$ of methylbenzoate) ${ }^{13} \mathrm{C} \mathrm{NMR}\left(\mathrm{CDCl}_{3}\right) \delta$ 28.1, 28.6, 50.6, 51.9, 55.5, 56.7, 71.5, 71.6, 113.7, $114.2(2 \mathrm{x}), 114.9,122.7,124.5,127.5,131.6(2 \mathrm{x}), 134.6$, 155.2 (2x), 162.5, 166.9. LRMS calculated for $\mathrm{C}_{21} \mathrm{H}_{26} \mathrm{NO}_{5}(\mathrm{M}+\mathrm{H}) 372.18$, found 372.15 .

\subsection{Hydrolysis of the MOM Group: Synthesis of Compound 10}

Compound $7(27 \mathrm{mg}, 0.07 \mathrm{mmol})$ was dissolved in acetone $(3 \mathrm{~mL})$, a solution of $10 \%$ hydrochloric acid in acetone $(1 / 1, \mathrm{v} / \mathrm{v})(8.4 \mathrm{~mL})$ was added and the resulting mixture was heated for $4 \mathrm{~h}$ at $57^{\circ} \mathrm{C}$. Water was then added, the acetone evaporated under reduced pressure, the solution neutralised with a saturated aqueous solution of sodium bicarbonate and the aqueous phase extracted with DCM. The organic phase was evaporated and purified by successive trituration in diethyl ether and hexanes to yield compound 10 ( $20 \mathrm{mg}, 83 \%$ yield) as a white powder.

Methyl 4-[2-hydroxy-4-(6-hydroxy-3,4-dihydroisoquinolin-2(1H)-yl)butoxy]benzoate (10): $\mathrm{Rf}=0.10$ (DCM/MeOH, 9:1). IR (film) v $3360\left(\mathrm{OH}\right.$ and $\left.\mathrm{NH}_{2}\right), 2924,1666$ (CON, amide), 1624, 1582, 1420, 1331, 1288, 1246, 1119. ${ }^{1} \mathrm{H}$ NMR (CD $\left.{ }_{3} \mathrm{OD}\right) \delta 1.90$ (m, $\underline{\mathrm{CH}}_{2}-\mathrm{CH}-\mathrm{O}$ ), 2.68-2.90 (broad m, Ar- $\underline{\mathrm{CH}}_{2} \mathrm{CH}_{2}-\mathrm{N}-\underline{\mathrm{CH}}_{2}$ ), 3.58 (s,

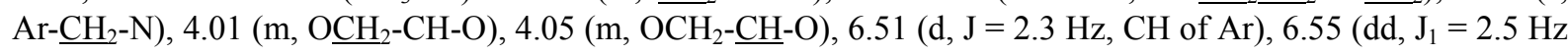


and $\mathrm{J}_{2}=8.2 \mathrm{~Hz}, \mathrm{CH}$ of $\left.\mathrm{Ar}\right), 6.83(\mathrm{~d}, \mathrm{~J}=8.3 \mathrm{~Hz}, \mathrm{CH}$ of $\mathrm{Ar}), 7.15(\mathrm{~d}, \mathrm{~J}=8.3 \mathrm{~Hz}, \mathrm{CH}$ of benzamide $), 7.37(\mathrm{t}, \mathrm{J}=8.2$ $\mathrm{Hz}, \mathrm{CH}$ of benzamide) 7.44 (m, $2 \mathrm{x} \mathrm{CH}$ of benzamide). ${ }^{13} \mathrm{C} \mathrm{NMR}\left(\mathrm{CD}_{3} \mathrm{OD}\right) \delta 29.8,31.1,52.1,56.3,56.8,70.3$, $73.3,114.6,115.1,116.1,119.5,121.0,125.2,128.4,130.6,135.9,136.3,158.5,160.5,172.2$. LRMS calculated for $\mathrm{C}_{20} \mathrm{H}_{25} \mathrm{~N}_{2} \mathrm{O}_{4}(\mathrm{M}+\mathrm{H}) 357.17$, found 357.15 .

$2.917 \beta$-HSD1 Inhibition of Compounds 8-10

The enzymatic assay was performed using the T-47D breast cancer cell line as source of $17 \beta$-HSD 1 activity following a procedure previously published (Ayan et al., 2012).

\subsection{Estrogenic Activity of Compounds 8 and 10}

Using a procedure we previously published (Ayan et al., 2012), compounds 8 and 10 were tested to determine their potential proliferative (estrogenic) effect on estrogen-sensitive (ER ${ }^{+}$) breast cancer T-47D cells.

\subsection{ER- $\alpha$ Binding Affinity of Compounds 8 and 10}

A comparative binding assay using a purified full-length recombinant human estrogen receptor alpha (ER- $\alpha$ ) was done as previously described (Ayan et al., 2012).

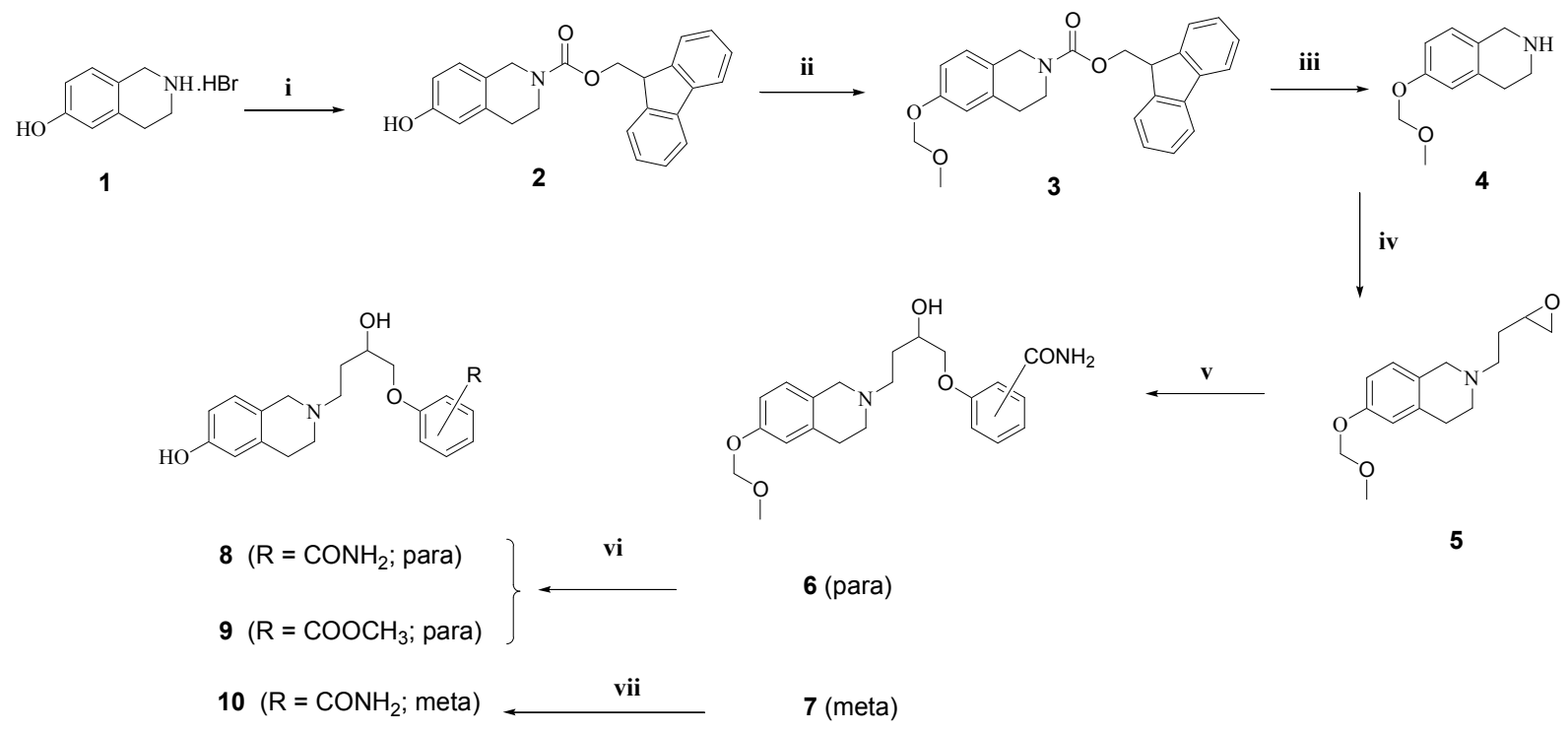

Figure 4. Synthesis of targeted compounds 8 and 10. Reagents and conditions: i) $\mathrm{THF} / \mathrm{H}_{2} \mathrm{O}, \mathrm{NaHCO}_{3}, \mathrm{Fmoc}-\mathrm{OSu}$, rt; ii) $\mathrm{CH}_{2} \mathrm{Cl}_{2}, \mathrm{ClCH}_{2} \mathrm{OCH}_{3}$, DIPEA, $0^{\circ} \mathrm{C}$ - rt; iii) piperidine; $\mathrm{CH}_{2} \mathrm{Cl}_{2}$, rt; iv) 4-bromo-1,2-epoxybutane, $\mathrm{K}_{2} \mathrm{CO}_{3}$, acetone, $55^{\circ} \mathrm{C}$; v) $\mathrm{K}_{2} \mathrm{CO}_{3}$, para- or meta- hydroxybenzamide, $\mathrm{DMF}, 105^{\circ} \mathrm{C}$; vi) $\mathrm{MeOH} / \mathrm{HCl}, 65^{\circ} \mathrm{C}$; vii) acetone $/ \mathrm{HCl}, 57^{\circ} \mathrm{C}$

\section{Results and Discussion}

\subsection{Synthesis of Targeted Compounds 8 and 10 (Figure 4)}

The free amine function of tetrahydro-6-isoquinolinol hydrobromide (1) was protected with Fmoc-Osu in presence of aqueous $\mathrm{NaHCO}_{3}$. The hydroxyl group of 2 was next protected as a methoxymethyl (MOM) ether group to give compound 3. This compound was found to be unstable at room temperature and has to be used readily to the next step. The Fmoc protecting group of 3 was then hydrolysed by a treatment with a mixture of piperidine in methylene chloride to give compound 4. An undesirable adduct of compound 4 with dibenzofulvene was however observed, thus reducing the yield of the reaction. A nucleophilic substitution of 4-bromo-1,2-epoxybutane by the free amine function of 4 yielded the epoxide 5. Para and meta hydroxybenzamide were used to open the epoxide and generate the corresponding alcohols 6 and 7. The final compounds 8 and 10 were obtained from acidic hydrolysis of 6 and 7, respectively, but the use of solvent, methanol or acetone, greatly influenced the yield of each compound. In fact, the side product 9 (methyl ester) was isolated from the hydrolysis of 6 when methanol was used instead of acetone, thus reducing the yield of compound 8 . A very good yield of compound $10(83 \%)$ was however obtained when we used acetone instead of methanol for the hydrolysis of 7 . 

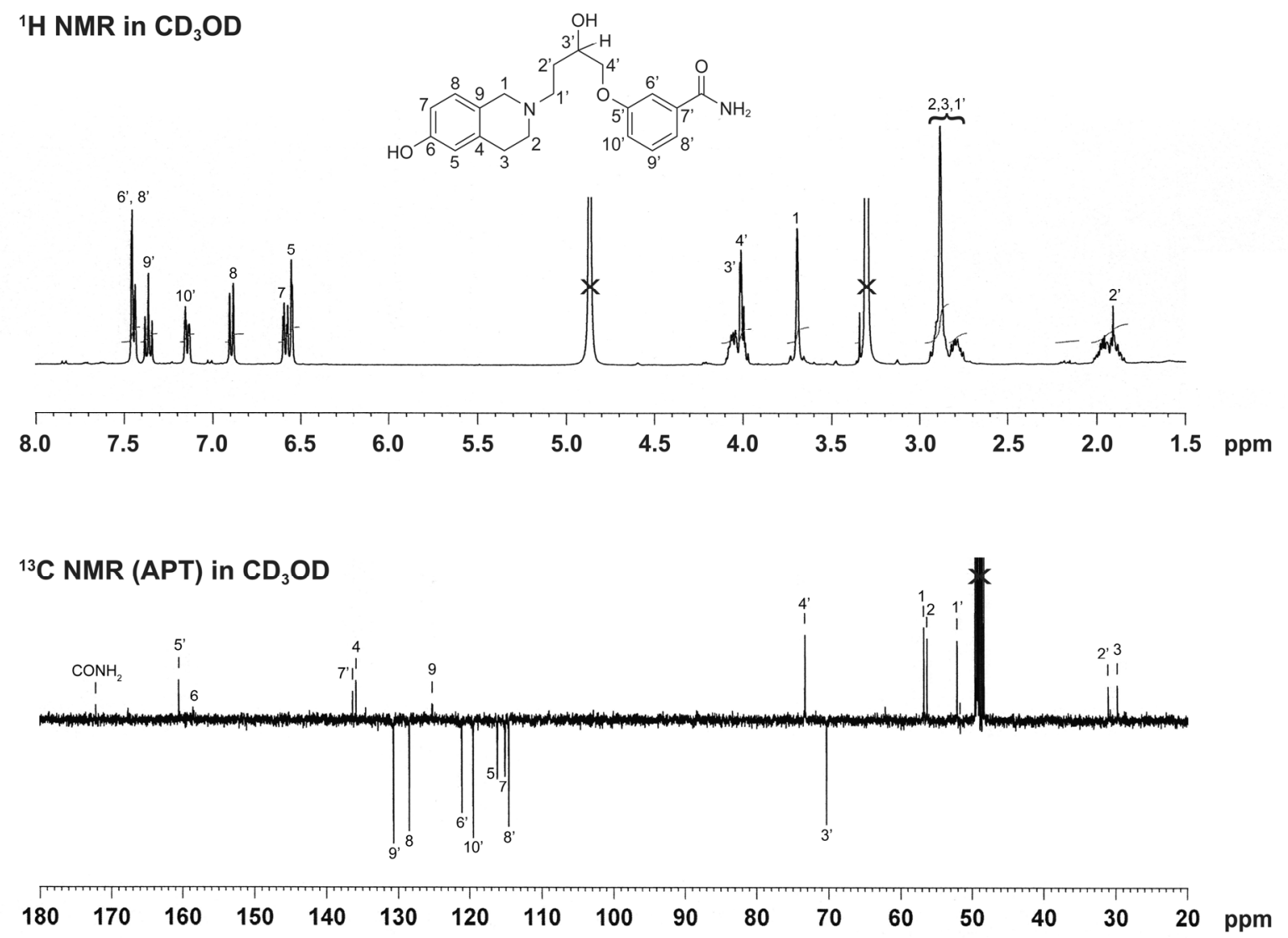

Figure 5. ${ }^{1} \mathrm{H}$ NMR and ${ }^{13} \mathrm{C}$ NMR (APT) spectra of final compound 10 dissolved in methanol- $\mathrm{d}_{4}$. All protons and carbons were assigned to the appropriate signals

\section{$3.2{ }^{13}$ C NMR Characterization of the Intermediate and Final Compounds}

The assignment of ${ }^{13} \mathrm{C}$ NMR signals (Table 1) for all compounds was performed using a combination of 2D NMR (APT, HSQC, HMBC, COSY and NOESY) experiments (Claridge, 1999). To illustrate our strategy, we selected the final compound 10 (Figure 5). We started our analysis with the only $\mathrm{CH}$ non aromatic signal at 70.3 and $4.05 \mathrm{ppm}$, which were easily identified as $\mathrm{C}^{\prime}$ ' and $\mathrm{H} 3$ ', respectively, from APT and HSQC spectra. From these signals, protons and carbons $1,2,3,1^{\prime}, 2^{\prime}$ and $4^{\prime}$ 'were distinctively assigned according to correlations observed in COSY, HSQC or/and HMBC. In fact, from cross-correlation in COSY spectrum, the H3' signal (4.05 ppm) showed two expected correlations: the first attributed to $\mathrm{H}^{\prime}$ ' $(1.90 \mathrm{ppm})$ and the other to $\mathrm{H} 4$ ' (4.01 ppm), no more correlation being observed for $\mathrm{H}^{\prime}$ ' in COSY spectrum as expected. Proton $\mathrm{H} 2$ ' showed one more cross-correlation with the signal at $2.78 \mathrm{ppm}$, so we thus assigned this chemical shift value to H1'. Proton H1 (3.58 ppm) is distinguishable from $\mathrm{H} 2$ and $\mathrm{H} 3$, as it did not show cross-correlation in COSY experiment. However, a correlation appears between the two signals at 2.74 and $2.83 \mathrm{ppm}$. To differentiate $\mathrm{H} 2$ from $\mathrm{H} 3$, we next used the results of HMBC experiment. In fact, proton $\mathrm{H} 3(2.85 \mathrm{ppm})$ distinctively showed four correlations in the HMBC spectrum (as expected with $\mathrm{C} 2, \mathrm{C} 4, \mathrm{C} 5$ and $\mathrm{C} 9$ ), and protons $\mathrm{H} 2$ (2.74 ppm) did not show long range coupling with $\mathrm{C} 9$, only one resolved signal being observed (attributed to $\mathrm{C} 4$ ). From each $\mathrm{H}$ signal reported above the corresponding $\mathrm{C}$ was easily identified using the HSQC spectrum.

After we identified the $\mathrm{CH}_{2}$ signals and the non-aromatic $\mathrm{CH}$ signal, two groups of aromatic $\mathrm{CH}$ and $\mathrm{C}$ signals remained to be assigned: those in the left part of the molecule (A-ring: C4-C9) and those in the right part of the molecule (C-ring: C5'-C10'). For the former ring system, aromatic protons H5, H7 and H8 are obviously assigned from their multiplicity and COSY experiment. Moreover, a strong cross-correlation was observed in NOESY spectrum between the proton $\mathrm{H} 1(3.58 \mathrm{ppm})$ and a proton at $6.83 \mathrm{ppm}$. This doublet signal $(\mathrm{J}=8.3 \mathrm{~Hz})$ was then associated to H8. Using the HSQC data, the C8 was next assigned to the peak at $128.4 \mathrm{ppm}$. By combining the COSY correlations between $\mathrm{H} 8$ and H7 and the HSQC data, we identified H7 (6.55 ppm) and C7 (115.1 ppm). From the NOESY spectrum, a cross-correlation was observed between the known H3 signal and the unknown $\mathrm{CH}$ signal at $6.51 \mathrm{ppm}$, this later was thus assigned to H5. C5 (116.1 ppm) was then identified from 
H5 using the HSQC spectrum. In HMBC spectrum, only C4 (135.9 ppm) can correlate with H1, H2 and H3, only C9 (125.2 ppm) can correlate with both H1, H3 and H7 signals, and only C6 (158.5 ppm) correlated with H5, H7 and $\mathrm{H} 8$.

Table $1 .{ }^{13} \mathrm{C}$ NMR assignation of intermediates and final compounds

\begin{tabular}{|c|c|c|c|c|c|c|c|c|c|}
\hline $\mathrm{Cpds}^{\mathrm{a}}$ & 2 & 3 & 4 & 5 & 6 & 7 & 8 & 9 & 10 \\
\hline $\mathrm{R}_{1}$ & $\mathrm{H}$ & $\mathrm{MOM}^{\mathrm{b}}$ & $\mathrm{MOM}$ & MOM & $\mathrm{MOM}$ & MOM & $\mathrm{H}$ & $\mathrm{H}$ & $\mathrm{H}$ \\
\hline $\mathrm{R}_{2}$ & --- & ---- & ---- & ---- & $p-\mathrm{CONH}_{2}$ & $m-\mathrm{CONH}_{2}$ & $p-\mathrm{CONH}_{2}$ & $p-\mathrm{COOCH}_{3}$ & $m-\mathrm{CONH}_{2}$ \\
\hline Solvent & $\mathrm{CDCl}_{3}$ & $\mathrm{CDCl}_{3}$ & $\mathrm{CDCl}_{3}$ & $\mathrm{CDCl}_{3}$ & $\mathrm{CDCl}_{3}$ & $\mathrm{CDCl}_{3}$ & $\mathrm{CD}_{3} \mathrm{OD}$ & $\mathrm{CDCl}_{3}$ & $\mathrm{CD}_{3} \mathrm{OD}$ \\
\hline $\mathrm{C} 1$ & 45.3 & 45.1 & 43.6 & 54.7 & 55.7 & 55.6 & 55.9 & 55.5 & 56.8 \\
\hline $\mathrm{C} 2$ & 41.4 & 41.2 & 47.6 & 55.6 & 56.8 & 56.6 & 55.8 & 56.7 & 56.3 \\
\hline $\mathrm{C} 3$ & 28.7 & 28.7 & 29.3 & 29.3 & 29.1 & 29.0 & 28.6 & 28.6 & 29.8 \\
\hline $\mathrm{C} 4$ & 135.9 & 135.5 & 135.5 & 135.5 & 135.1 & 135.1 & 135.1 & 134.6 & 135.9 \\
\hline $\mathrm{C} 5$ & 115.1 & 115.8 & 116.5 & 115.8 & 115.8 & 115.7 & 115.7 & 114.9 & 116.1 \\
\hline C6 & 154.2 & 155.6 & 155.4 & 155.5 & 155.7 & 155.7 & 157.6 & 155.2 & 158.5 \\
\hline $\mathrm{C} 7$ & 114.9 & 114.6 & 114.3 & 114.2 & 114.4 & 114.5 & 115.0 & 113.7 & 115.1 \\
\hline $\mathrm{C} 8$ & 127.4 & 127.1 & 127.5 & 127.5 & 127.5 & 127.5 & 128.8 & 127.5 & 128.4 \\
\hline C9 & 133.1 & 126.3 & 129.3 & 128.2 & 127.4 & 127.2 & 127.3 & 124.5 & 125.2 \\
\hline $\mathrm{C} 1$, & 155.5 & 155.2 & ---- & 50.8 & 50.5 & 50.5 & 51.7 & 50.6 & 52.1 \\
\hline $\mathrm{C} 2$ ' & 67.5 & 67.2 & ---- & 30.5 & 28.5 & 28.5 & 30.3 & 28.1 & 31.1 \\
\hline $\mathrm{C} 3$, & 47.3 & 47.2 & ---- & 50.9 & 71.5 & 71.4 & 69.7 & 71.5 & 70.3 \\
\hline $\mathrm{C} 4$, & 144.0 & 143.9 & ---- & 47.1 & 71.8 & 71.9 & 73.2 & 71.6 & 73.3 \\
\hline $\mathrm{C} 5$ & 125.0 & 124.8 & ---- & ---- & 161.9 & 159.0 & 163.3 & 162.5 & 160.5 \\
\hline $\mathrm{C} 6{ }^{\prime}$ & 127.0 & 126.9 & ---- & ---- & 114.3 & 119.5 & 115.3 & 114.2 & 121.0 \\
\hline $\mathrm{C} 7$ & 127.7 & 127.5 & ---- & ---- & 129.3 & 134.8 & 130.7 & 131.6 & 136.3 \\
\hline $\mathrm{C} 8$ & 120.0 & 119.8 & ---- & ---- & 125.7 & 113.4 & 123.8 & 122.7 & 114.6 \\
\hline C9, & 141.3 & 141.2 & ---- & ---- & 129.3 & 129.6 & 130.7 & 131.6 & 130.6 \\
\hline $\mathrm{C} 10$ & ---- & ---- & ---- & ---- & 114.3 & 118.6 & 115.3 & 114.2 & 119.5 \\
\hline COX & ---- & ---- & ---- & ---- & 168.9 & 169.2 & 172.0 & 166.9 & 172.1 \\
\hline $\mathrm{OCH}_{2} \mathrm{O}$ & ---- & 94.3 & 94.5 & 94.5 & 94.5 & 94.5 & ---- & ---- & ---- \\
\hline $\mathrm{OCH}_{3}$ & ---- & 55.8 & 55.9 & 55.9 & 55.9 & 55.9 & ---- & 51.9 & ---- \\
\hline
\end{tabular}

a-See Figure 6 for structural formulae and carbon numbering.

b-MOM: $\mathrm{OCH}_{2} \mathrm{OCH}_{3}$. 


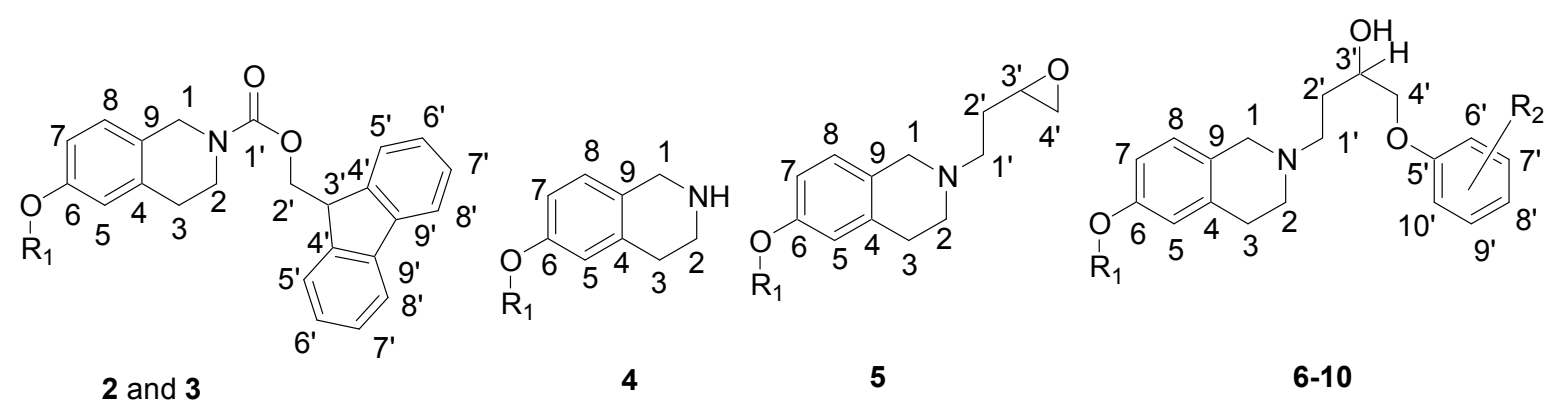

Figure 6. Structural formulae and carbon numbering of compounds 2 to 10

For the C-ring system, the C5' $(160.5 \mathrm{ppm})$ was identified by a characteristic HBMC correlation with the previously assigned H4' signal. The carboxamide carbon (172.2 ppm) was also assigned by comparison with literature data for a similar benzamide group. We next identified H6' $(7.47 \mathrm{ppm})$ because it is the only proton producing correlations with both $\mathrm{C}^{\prime}$ ' and $\mathrm{CONH}_{2}$. From H6' we also identified C6' (121.0 ppm) with HSQC experiment. The apparent triplet at $7.37 \mathrm{ppm}$ with a large coupling constant $(8.2 \mathrm{~Hz})$ was necessarily the $\mathrm{H} 9$ ', which correlated in HSQC experiment with the peak at $130.6 \mathrm{ppm}$ (C9'). The H9' signal showed four cross-correlations in $\mathrm{HMBC}$ (as expected with $\mathrm{C}^{\prime}, \mathrm{C} 7$ ', C8', and $\mathrm{C} 10^{\prime}$ ). Since $\mathrm{C}^{\prime}$ ' was previously assigned, the other quaternary carbon in this group is necessary C7' (136.3 ppm). To discriminate the two remaining H8' and H10' signals we used the NOESY experiment which showed a correlation with H10' (7.15 ppm) but not with H8' (7.45 ppm). Using the HSQC spectrum, we then assigned C10' at $119.5 \mathrm{ppm}$ and $\mathrm{C} 8$ ' at $114.6 \mathrm{ppm}$.

\subsection{Biological Evaluation of Compounds 8-10}

The inhibitory potency of compounds 8,9 and 10 on $17 \beta$-HSD1 was assessed at $0.1,1$ and $10 \mu \mathrm{M}$ in intact T-47D cells, which are able to transform E1 to E2 and are known to be a good source of 17ß-HSD1 (Day et al., 2008a; Laplante et al., 2009). Cells were co-incubated for $24 \mathrm{~h}$ with each compound to be tested and radiolabeled E1 $(60 \mathrm{nM})$. Inhibitory effect of compounds was compared with unlabeled estrone and CC-156, each used as an inhibitor, after separation and quantification of radiolabeled steroids (E1 and E2). Although docking experiments gave us expectation of a good affinity of the target compound 10 with the enzyme (17ß-HSD1), we were disappointed by the results of our enzymatic assay because compounds 8, 9 and 10 did not inhibit the transformation of E1 to E2 by 17ß-HSD1 found in T-47D cells. This might be due to poor accessibility of these compounds to the cell cytoplasm where 17ß-HSD1 is located, but this has to be verified by a biological test on homogenized cells. Moreover, the alkyl side chain between the phenyl rings render the molecules more flexible, with a higher degree of freedom compared to $\mathrm{CC}-156$ where the rigidity is provided by the estrane scaffold. The electronic character of the pseudo-cycle B due to the presence of a nitrogen atom is another possible cause of the weaker affinity of compounds 8-10 with the enzyme.

One important objective of our project was to obtain a compound that is devoid of estrogenic activity. The proliferation of estrogen-sensitive $\left(\mathrm{ER}^{+}\right) \mathrm{T}-47 \mathrm{D}$ cells was then carried out to determine the estrogenic activity of compounds 8 and 10. In this assay, an estrogenic compound will stimulate the proliferation of $\mathrm{ER}^{+}$cells, as observed when we used E2 as a reference compound. Thus, a treatment with $0.1 \mathrm{nM}$ of E2 during seven days increased the cell proliferation from $100 \%$ (control) to $153 \%$. Interestingly, compound 8 (para) did not show any proliferative (estrogenic) activity at the six concentrations tested $(0.001,0.01,0.1,1,5$ and $10 \mu \mathrm{M})$. Compound 10 (meta) showed no estrogenic activity at $0.001,0.01,0.1$ and $1 \mu \mathrm{M}$ but increased the cell proliferation to 125 and $129 \%$ at 5 and $10 \mu \mathrm{M}$, respectively. The binding affinity of compounds 8 and 10 was next carried out using the human ER $\alpha$. In this competition binding assay, an estrogenic compound will displace the tritiated E2 $\left(\left[{ }^{3} \mathrm{H}\right]-\mathrm{E} 2\right)$, and the remaining bound $\left[{ }^{3} \mathrm{H}\right]-\mathrm{E} 2$ will be measured and used to determine the affinity of this compound for ER $\alpha$. Thus, when untritiated E2 was used as a reference compound in a range of concentration $\left(10^{-12}-10^{-5} \mathrm{M}\right)$, an effective concentration of $2.3 \pm 0.4 \mathrm{nM}$ was needed to displace $50 \%$ of $2.5 \mathrm{nM}$ of $\left[{ }^{3} \mathrm{H}\right]-\mathrm{E} 2$. Interestingly, both compounds 8 and 10 did not show any affinity to ER $\alpha$ in concentrations ranging from $10^{-12}$ to $10^{-5} \mathrm{M}$.

\section{Conclusion}

We have synthesized non-steroidal mimics of CC-156, a potent steroidal inhibitor of 17ß-HSD1, but they did not inhibit the transformation of E1 to E2 by 17ß-HSD1 found in T-47D cells. The flexibility of compounds 8 and 10, 
compared to the rigid steroid backbone of CC-156, is potentially responsible for their lack of enzyme inhibitory activity. It is however interesting to mention that compounds 8 and 10 did not bind to ER $\alpha$ and did not induce the proliferation of estrogen-sensitive (ER ${ }^{+}$T-47D cells, except compound 10 at high concentrations of 5 and 10 $\mu \mathrm{M}$, suggesting that they are not estrogenic compounds. We also fully characterized all intermediate and final compounds, and the synthetic approach we developed is now available to generate additional analogs.

\section{Acknowledgements}

This work was supported by the Canadian Institutes of Health Research (CIHR). The authors would like to thank Diane Fournier for the docking experiments and Marie-Claude Trottier for the NMR and LRMS experiments. Careful reading of the manuscript by Micheline Harvey is also greatly appreciated.

\section{References}

Ayan, D., Maltais, R., Roy, J., \& Poirier, D. (2012). A new non-estrogenic steroidal inhibitor of $17 \beta$-hydroxysteroid dehydrogenase type 1 blocks the estrogen-dependent breast cancer tumor growth induced by estrone. Mol. Cancer Ther., 11, 2096-2104. http://dx.doi.org/ 10.1158/1535-7163.MCT-12-0299

Claridge, T. D. W. (1999). High-resolution NMR techniques in Organic chemistry. New York: Pergamon.

Day, J. M., Foster, P. A., Tutill, H. J., Parsons, M. F., Newman, S. P., Chander, S. K., ... Purohit, A. (2008a). 17beta-hydroxysteroid dehydrogenase type 1 , and not type 12, is a target for endocrine therapy of hormone-dependent breast cancer. Int. J. Cancer, 122, 1931-1940. http://dx.doi.org/ 10.1002/ijc.23350

Day, J. M., Tutill, H. J., Purohit, A., \& Reed, M. J. (2008b). Design and validation of specific inhibitors of $17 \beta$-hydroxysteroid dehydrogenases for therapeutic application in breast and prostate cancer, and in endometriosis. Endocr-Relat. Cancer, 15, 665-692. http://dx.doi.org/10.1677/ERC-08-0042

Dizerega, G. S., Barber, D. L., \& Hodgen, G. D. (1980). Endometriosis: Role of ovarian steroids in initiation, maintenance and suppression. Fert. Steril., 33, 649-653.

Jemal, A., Bray, F., Center, M. M., Ferlay, J., \& Ward, E. (2011). Global Cancer Statistics. CA Cancer J. Clin., 61, 69-90. http://dx.doi.org/10.3322/caac.20107

Labrie, F. (1991). Intracrinology. Mol. Cell. Endocrinol., 78, C113-C118. http://dx.doi.org/10.1016/0303-7207(91)90116

Laplante, Y., Cadot, C., Fournier, M. A., \& Poirier, D. (2008). Estradiol and estrone C-16 derivatives as inhibitors of type 1 17 $\beta$-hydroxysteroid dehydrogenase: Blocking of $\mathrm{ER}^{+}$breast cancer cell proliferation induced by estrone. Bioorg. Med. Chem., 16, 1849-1860. http://dx.doi.org/10.1016/j.bmc.2007.11.007

Laplante, Y., Rancourt, C., \& Poirier, D. (2009). Relative involvement of three 17ß-hydroxysteroid dehydrogenases (types 1, 7 and 12) in the formation of estradiol in various breast cancer cell lines using selective inhibitors. Mol. Cell. Endocrinol., 301, 146-153. http://dx.doi.org/10.1016/jmce.2008.08.026

Mazumdar, M., Fournier, D., Zhu, D., Cadot, C., Poirier, D., \& Lin, S. (2009). Binary and ternary crystal structure analyses of a novel inhibitor with $17 \beta$-HSD type 1: a lead compound for breast cancer therapy. Biochem. J., 424, 357-366. http://dx.doi.org/doi:10.1042/ BJ20091020

Poirier, D. (2008). New cancer drugs targeting the biosynthesis of estrogens and androgens. Drug Dev. Res., 69 , 304-318. http://dx.doi.org/doi:10.1002/ddr.20263

Poirier, D. (2010). 17ß-Hydroxysteroid dehydrogenase inhibitors: a patent review. Expert Opin. Ther. Patents, 20, 1123-1145. htpp://dx.doi.org/doi.10.1517/13543776.2010.505604

Poirier, D. (2011) Contribution to the development of inhibitors of $17 \beta$-hydroxysteroid dehydrogenase types 1 and 7: Key tools for studying and treating estrogen-dependent diseases. J. Steroid Biochem. Molec. Biol., 125, 83-94. htpp://dx.doi.org/10.1016/ j.jsbmb.2010.12.007

Simard, J., Vincent, A., Duchesne, R., \& Labrie, F. (1988). Full oestrogenic activity of C19-delta 5 adrenal steroids in rat pituitary lactotrophs and somatotrophs. Mol. Cell. Endocrinol., 55, 233-242. http://dx.doi.org/10.1016/0303-7207(88)90138-4

Travis, R. C., \& Key, T. J. (2003). Estrogen exposure and breast cancer risk. Breast Cancer Res., 5, 239-247. http://dx.doi.org/10.1186/bcr628 